\title{
Potassium fertilization via fertigation and conventional application on quality of tomato fruits
}

\author{
Mário de O. Rebouças Neto ${ }^{1}$, Benito M. de Azevedo², Thales V. de A. Viana², \\ José B. R. de Mesquita ${ }^{3}$, Marco A. R. de Carvalho ${ }^{4}$ \& Lilian C. C. de Carvalho ${ }^{4}$ \\ ${ }^{1}$ Instituto Federal de Educação, Ciência e Tecnologia do Piauí. Campo Maior, PI. E-mail: agromario@gmail.com (Corresponding author) \\ ${ }^{2}$ Universidade Federal do Ceará/Departamento de Engenharia Agrícola. Fortaleza, CE. E-mail: benito@ufc.br; thales@ufc.br \\ ${ }^{3}$ Faculdade de Tecnologia do Nordeste/Departamento de Engenharia Agrícola. Fortaleza, CE. E-mail: agronobruno@gmail.com \\ ${ }^{4}$ Instituto Federal de Educação, Ciência e Tecnologia do Ceará. Sobral, CE. E-mail: marcorosa@ifce.edu.br; liliancarv@ifce.edu.br
}

\section{Key words:}

Lycopersicon esculentum

fertigation

$\mathrm{KCl}$

postharvest

\begin{abstract}
A B S T R A C T
The tomato crop plays an important environmental, economic and even social role, especially for creating employment and income. The present work aims to evaluate the effects of potassium (K) drip fertigation and of conventional $\mathrm{K}$ fertilization on the tomato crop quality. The experiment was conducted under field conditions, in the period between August 2011 and December 2011, in Fortaleza, CE, Brazil. The experimental design was in randomized blocks in a factorial arrangement and the treatments corresponded to doses $(\mathrm{D} 1=200, \mathrm{D} 2=400$ and D3 = $800 \mathrm{~kg} \mathrm{~K}_{2} \mathrm{O} \mathrm{ha}^{-1}$ ) and $\mathrm{K}$ fertilizing methods (F1 - Fertigation and F2 - Conventional fertilization), plus an additional control (without $\mathrm{K}$ fertilization) for each fertilizing method, with four replicates. The following variables were analyzed: fruit firmness (FF), soluble solids content (SS), titratable acidity (TA), $\mathrm{pH}$ and SS/TA ratio. $\mathrm{K}$ fertilization through fertigation $\left(400 \mathrm{~kg} \mathrm{~K}_{2} \mathrm{O} \mathrm{ha}^{-1}\right)$ increases SS and the SS/TA ratio of the tomato fruits. Thus, $\mathrm{K}$ fertigation is the most promising method, since it allows the use of a lower $\mathrm{K}$ dose.
\end{abstract}

\section{Palavras-chave:}

Lycopersicon esculentum fertigação

$\mathrm{KCl}$

pós-colheita

\section{Adubação potássica via fertigação e aplicação convencional na qualidade de frutos de tomate}

\section{R E S U M O}

A cultura do tomateiro desempenha papel relevante socioambiental e econômico, notadamente pela possibilidade de sua utilização como matéria prima na geração de emprego e renda. Objetivou-se, com o presente trabalho, a avaliação do efeito da adubação potássica aplicada via fertigação por gotejamento e de forma convencional na qualidade de frutos de tomate. O experimento foi conduzido em campo, no período entre agosto e dezembro de 2011, em Fortaleza, Ceará. O delineamento experimental foi em blocos ao acaso no esquema fatorial sendo estudados os fatores doses (D1 = 200; D2 $=400$ e D3 $=800 \mathrm{~kg} \mathrm{ha}^{-1}$ de $\mathrm{K}_{2} \mathrm{O}$ ) e formas de aplicação (F1 - Fertirrigação e F2 - Adubação convencional) e uma testemunha adicional (controle-sem adubo potássico) para cada forma de aplicação com quatro repetições. Foram analisadas as seguintes variáveis: firmeza dos frutos (FF), teor de sólidos solúveis (SS), acidez titulável (AT), pH e a relação (SS/AT). A adubação potássica aplicada de forma fertigada $\left(400 \mathrm{~kg} \mathrm{ha}^{-1} \mathrm{de}_{2} \mathrm{O}\right)$ aumenta os SS e a relação SS/AT dos frutos de tomateiro. Desta forma, a fertigação potássica é mais promissora haja vista que este método permite maior fracionamento das doses a serem aplicadas. 


\section{INTRODUCTION}

The tomato plant can be cultivated in tropical and subtropical regions worldwide, for both fresh consumption, cultivated using stakes, and processing industry, cultivated without support (Santos et al., 2011).

Brazil occupies the eighth place in the production ranking with 4.4 million tons in 2011 in 72 thousand ha planted (FAO, 2013).

In the Northeast, the crop is mainly cultivated by small rural producers and the Ceará state is the third largest producer (18.4\%). However, in terms of value of production, in 2011, it occupied the second place, contributing with $24.4 \%$ of the total in the region (IBGE, 2013).

In the composition of tomato fruits, there are changes that have been studied through some quality characteristics, such as: fruit size, acidity, soluble solids, content of sugars and texture, among others (Ferreira et al., 2010).

Potassium $\left(\mathrm{K}_{2} \mathrm{O}\right)$ is the nutrient most absorbed by tomato plants and is essential for many physiological processes, such as photosynthesis, enzymatic activation and synthesis of proteins (Kanai et al., 2011), as well as soluble solids (SS) and titratable acidity (TA) (Blanco \& Folegatti, 2008).

$\mathrm{K}$ deficiency limits photosynthesis in the leaves and the transport of photoassimilates to the tomato fruits, causing reduction in fruit quality (Dorais et al., 2008).

On the other hand, K excess can limit the absorption of $\mathrm{Ca}$ and $\mathrm{Mg}$, ultimately leading to the deficiency of these elements (Vasconcelos et al., 2013).

K can be applied through the conventional method, which consists in the application of the fertilizer directly in the soil along the sowing row (Sousa et al., 2013), and through fertigation, which reduces the costs with labor in fertilization and increases the efficiency of the mineral element in the soil management (Pereira et al., 2010).

This study aimed to evaluate the effect of $\mathrm{K}$ fertilization through drip fertigation and conventional application on the post-harvest quality of tomato fruits.

\section{Material ANd Methods}

The field experiment was conducted in 2011, in an area located at the Federal University of Ceará (UFC), Campus of Pici, in Fortaleza, CE, Brazil (344' 45” S; 38 34' 55” W; 20 m). According to Köppen's classification, the climate of the region is Aw', characterized as rainy tropical. The meteorological data collected along the experiment are shown in Table 1.

The soil in the experimental area was classified as Red Yellow Argisol with sandy loam texture (EMBRAPA, 2006). Before installing the experiments, composite soil samples were

Table 1. Monthly data of the climatic variables along the experiment

\begin{tabular}{lcccc}
\hline Month & $\begin{array}{c}\text { Air } \\
\text { temperature } \\
\left({ }^{\circ} \mathbf{C}\right)\end{array}$ & $\begin{array}{c}\text { Relative } \\
\text { humidity } \\
(\%)\end{array}$ & $\begin{array}{c}\text { Wind } \\
\text { speed } \\
\left(\mathbf{m ~ s}^{-1}\right)\end{array}$ & $\begin{array}{c}\text { Rainfall } \\
(\mathbf{m m})\end{array}$ \\
August & 26.6 & 71.0 & 4.1 & 51.0 \\
September & 27.0 & 67.0 & 4.5 & 0.0 \\
October & 27.1 & 72.0 & 4.2 & 23.8 \\
November & 27.4 & 73.0 & 3.8 & 7.3 \\
December & 27.7 & 71.0 & 3.7 & 6.7 \\
\hline
\end{tabular}

Source: Weather Station of the Federal University of Ceará collected in the layer of $0.0-0.2 \mathrm{~m}$, with the aid of a Dutch auger; then, the samples were homogenized and subjected to laboratorial analyses for the estimation of physicalhydraulic characteristics. The mean values of field capacity

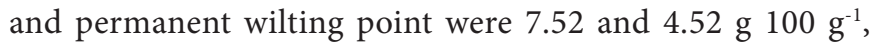
respectively. Soil density was calculated as $1.43 \mathrm{~g} \mathrm{~cm}^{-3}$, with the respective values of clay, silt, fine sand and coarse sand of: 113, 96, 386 and $405 \mathrm{~g} \mathrm{~kg}^{-1}$.

The experiment was conducted using the persimmon tomato crop (Lycopersicon esculentum, Mill), hybrid "Dominador F1" of the company Topseed, which has an indeterminate growth habit.

Prior to the transplanting of the tomato seedlings, a deep plowing was performed in the area, followed by two crossharrowings; then, the area was cleaned in order to remove crop residues from the soil, because they could somehow interfere with the installation of the irrigation system and the application of the treatments. Then, the area was manually leveled and the furrows were made with height of $20 \mathrm{~cm}$ and width of $30 \mathrm{~cm}$, in order to allow the deepening of the tomato roots.

Irrigations were performed through a drip system with mean flow rate of the emitters of $4.0 \mathrm{~L} \mathrm{~h}^{-1}$ and service pressure of $1.0 \mathrm{kgf} \mathrm{cm}^{-2}$.

The irrigation depth $(\mathrm{Li})$ was estimated based on the reference evapotranspiration (ETo) of Penman-Monteith, obtained with the data of an automatic weather station, equipped with sensors and accessories necessary for the estimation of ETo through the Penman-Monteith methodology (Allen et al., 1998).

Sowing was manually performed on polystyrene trays with 128 cells on July 15, 2011; after 26 days from sowing, the seedlings were transplanted to the field, at spacing of 1.0 $\mathrm{m}$ between rows and $0.5 \mathrm{~m}$ between plants in the same row.

Tomato fertilization consisted basically in the application of 300,200 and $400 \mathrm{~kg} \mathrm{ha}^{-1}$ of $\mathrm{N}, \mathrm{P}_{2} \mathrm{O}_{5}$ and $\mathrm{K}_{2} \mathrm{O}$, according to IAC (1996), respectively.

One third of the nitrogen was applied as basal fertilization, in the form of urea, corresponding to $11.11 \mathrm{~g}$ of urea per hole; the remaining two thirds of $\mathrm{N}$ were divided into 11 applications, via fertigation, which corresponded to the dose of $300 \mathrm{~kg} \mathrm{ha}^{-1}$ of $\mathrm{N}$. Phosphorus was totally applied as basal fertilization $\left(56 \mathrm{~g} \mathrm{hole}^{-1}\right)$, in the form of single superphosphate, corresponding to the dose of $200 \mathrm{~kg} \mathrm{ha}^{-1}$ of $\mathrm{P}_{2} \mathrm{O}_{5}$.

This experiment evaluated different $\mathrm{K}$ doses using $\mathrm{KCl}(60 \%$ of $\mathrm{K}_{2} \mathrm{O}$ ) applied in two forms: through the irrigation system (fertigation with white potassium chloride) and conventionally, using red potassium chloride in the amounts of 200, 400 and $800 \mathrm{~kg} \mathrm{ha}^{-1}$, which correspond respectively to the treatments: half the recommended dose, recommended dose and twice the dose recommended for the tomato crop, in both methods of application of the previously mentioned nutrient.

In the conventional fertilization, the three $\mathrm{K}_{2} \mathrm{O}$ doses were applied as follows: one third as basal, prior to transplanting, and two thirds as top-dressing 40 days after transplanting (DAT). On the other hand, $\mathrm{K}_{2} \mathrm{O}$ was not applied as basal fertilization in the fertigation, and all doses were applied through the irrigation system, divided into 11 applications performed according to the absorption rate of the crop, with the first application at $20 \mathrm{DAT}$. 
Harvest occurred from 70 to 90 DAT, when the fruits were manually collected; after harvest, the fruits were placed in plastic bags, arranged in boxes and transported to the Laboratory of Physiology and Postharvest Technology of the Embrapa Tropical Agroindustry, where they were analyzed for quality: fruit firmness (FF), content of soluble solids (SS), titratable acidity (TA), potential of hydrogen $(\mathrm{pH})$ and the ratio between soluble solids and titratable acidity (SS/TA).

Fruit firmness was measured in the equatorial region of whole fruits, using an automatic penetrometer with 6-mmdiameter tip, after removing a small portion of the periderm of the fruit with a knife. Firmness, the force necessary to break pulp resistance, was expressed in Newtons $(\mathrm{N})$.

The procedure of measuring soluble solids (SS) consisted in mixing and completely homogenizing the pulp of the sampled fruits; then, part of the juice was filtered in filter paper and two drops of the mixture were placed in a digital refractometer (ATAGO PR-101), with measuring scale from 0 to $45^{\circ} \mathrm{Brix}$, with subdivision in decimal scale (AOAC, 1992).

Titratable acidity (TA) was measured in duplicate by diluting $1.0 \mathrm{~g}$ of the pulp in $50 \mathrm{~mL}$ of distilled water; in the processing, titration was performed with $\mathrm{NaOH}(0.1$ $\mathrm{N})$ until reaching $\mathrm{pH}$ of 8.1 , with the aid of an automatic digital potentiometric titrator with glass membrane (Mettler DL12). The results were expressed in percentage of citric acid, according to IAL (2005).

$\mathrm{pH}$ was measured directly in the juice of the samples of each one of the replicates using a digital potentiometer (DMPH-2 Digimed) with glass membrane, assessed with buffer solutions with $\mathrm{pH}$ of 7 and 4, according to AOAC (1992).

This SS/TA ratio is represented by the quotient between soluble solids (SS) and titratable acidity (TA).

The experimental design was randomized blocks, with four replicates, in a $3 \times 2$ factorial scheme, with additional treatment for each one of the forms of $\mathrm{K}_{2} \mathrm{O}$ application, corresponding to the control treatment. The studied factors were $\mathrm{K}$ doses (D1 = 200; D2 = 400; D3 = $800 \mathrm{~kg} \mathrm{ha}^{-1}$ ) and the form of application (F1 - Fertigation; F2 - Conventional fertilization), besides the additional treatment (control).

The obtained results were subjected to analysis of variance and regression, and, according to the level of significance, to $\mathrm{F}$ test for the doses and forms of application. Polynomial regression analysis was used at 0.01 or 0.05 probability level, selecting the polynomial models of best fit. The analyses were performed using the computational programs Assistat 7.6.

\section{Results AND Discussion}

Table 2 shows the values of the analysis of variance for fruit firmness (FF), soluble solids (SS), potential of hydrogen $(\mathrm{pH})$, titratable acidity (TA) and the SS/TA ratio (SS/TA) of the tomato crop as a function of doses of $\mathrm{K}$ fertilization through the conventional and fertigated methods. The different $\mathrm{K}$ doses (200, 400 and $800 \mathrm{~kg} \mathrm{ha}^{-1}$ ) significantly influenced TA and SS/ TA at 0.05 probability level by $\mathrm{F}$ test, while for the forms of application (fertigated and conventional) there was no effect
Table 2. Summary of the analysis of variance for fruit firmness (FF), soluble solids (SS), potential of hydrogen $(\mathrm{pH})$, titratable acidity (TA) and SS/TA ratio (SS/TA) of the tomato crop under different $\mathrm{K}$ doses through fertigation and conventional application, at 90 DAT

\begin{tabular}{|c|c|c|c|c|c|c|}
\hline \multirow{2}{*}{$\begin{array}{c}\text { Source } \\
\text { of variation }\end{array}$} & \multirow{2}{*}{ DF } & \multicolumn{4}{|c|}{ Mean square } & \multirow{2}{*}{ SS/TA } \\
\hline & & FF & SS & $\mathrm{pH}$ & TA & \\
\hline Doses (D) & 2 & $0.086^{\text {ns }}$ & 0.620 ** & $0.000^{\text {ns }}$ & $0.051^{* *}$ & 37.663 ** \\
\hline Forms (F) & 1 & $0.093^{\text {ns }}$ & $0.039^{\text {ns }}$ & $0.000^{\text {ns }}$ & $0.004^{\text {ns }}$ & $0.234^{\text {ns }}$ \\
\hline Interaction D x F & 2 & $0.076^{\text {ns }}$ & $0.075^{\star}$ & $0.032^{\text {ns }}$ & $0.003^{\text {ns }}$ & $1.672^{\text {ns }}$ \\
\hline Factorial x C & 1 & $1.23^{* *}$ & $1.168^{* *}$ & $0.038^{\text {ns }}$ & $0.018^{* *}$ & $0.002^{\text {ns }}$ \\
\hline Treatments & 6 & $0.276^{\text {ns }}$ & $0.433^{* *}$ & $0.017^{\text {ns }}$ & $0.021^{* *}$ & $13.151^{* *}$ \\
\hline Residual & 18 & 0.109 & 0.017 & 0.009 & 0.001 & 0.799 \\
\hline Total & 27 & & & & & \\
\hline CV (\%) & - & 4.92 & 3.44 & 1.99 & 8.05 & 9.07 \\
\hline Overall mean & & 6.72 & 3.81 & 4.94 & 0.39 & 9.86 \\
\hline
\end{tabular}

DF - Degrees of freedom, CV - Coefficient of variation; C - Control

${ }^{* \star}$ Significant at $0.01,{ }^{*}$ Significant at 0.05 and ${ }^{\text {ns Not significant }}$

at 0.01 and 0.05 probability levels by $\mathrm{F}$ test on the variables studied in this experiment. The interaction between the factors significantly influenced only SS.

The non-significant effect on the variables $\mathrm{FF}$ and $\mathrm{pH}$ has been observed by other authors, testing the supply of $\mathrm{K}$ to the tomato crop (Schwarz et al., 2013).

The lack of variation in fruit firmness can be explained by the pectin, which is a polymer that is determinant for the firmness of the vegetables (Paiva et al., 2009). Gel formation is the main functional feature of the pectin, which is essentially dependent on the characteristics of the environment, such as pH (Ganez et al., 2006), which did not show significant difference. Sampaio \& Fontes (1998) tested two forms of application of $\mathrm{K}$ in the tomato crop and observed no significant effect on $\mathrm{pH}$, a result similar to that of the present study.

The significant interaction and the comparative analysis of the means through Tukey test, of the different $\mathrm{K}_{2} \mathrm{O}$ doses in each method of application, for the variable soluble solids, are presented in Table 3.

Comparing only the $\mathrm{K}$ application methods, for SS, only twice the recommended dose $\left(800 \mathrm{~kg} \mathrm{ha}^{-1}\right)$ applied through fertigation showed superiority in relation to the conventional method; the other tested doses (200 and $400 \mathrm{~kg} \mathrm{ha}^{-1}$ ) did not differ by Tukey test between both methods.

Zhao-Hui et al. (2008) reinforce that K, when applied correctly, increases the quality of tomato fruits.

According to the regression analysis (Figure 1), plants fertilized through fertigation showed higher values of soluble

Table 3. Mean values of the significant interactions of the analysis of variance referring to soluble solids (SS) of tomato fruits as a function of $\mathrm{K}$ doses $\left(\mathrm{kg} \mathrm{ha}^{-1}\right)$ through fertigation and conventional application

\begin{tabular}{|c|c|c|}
\hline \multirow{2}{*}{$\begin{array}{c}\text { Doses of } \mathrm{K}_{2} \mathrm{O} \\
\left(\mathrm{kg} \mathrm{ha}^{-1}\right)\end{array}$} & \multicolumn{2}{|c|}{ Application methods } \\
\hline & Fertigation & Conventional \\
\hline & \multicolumn{2}{|c|}{ Soluble solids ( ${ }^{\circ}$ Brix) } \\
\hline 200 & $3.61 \mathrm{a}$ & $3.74 \mathrm{a}$ \\
\hline 400 & $4.27 \mathrm{a}$ & $4.15 \mathrm{a}$ \\
\hline \multirow[t]{2}{*}{800} & $3.92 \mathrm{a}$ & $3.67 \mathrm{~b}$ \\
\hline & \multicolumn{2}{|c|}{ MSD row $=0.19$} \\
\hline
\end{tabular}

Means followed by the same letter in the row do not differ statistically by Tukey test at 0.05 probability level; MSD - Minimum significant difference 


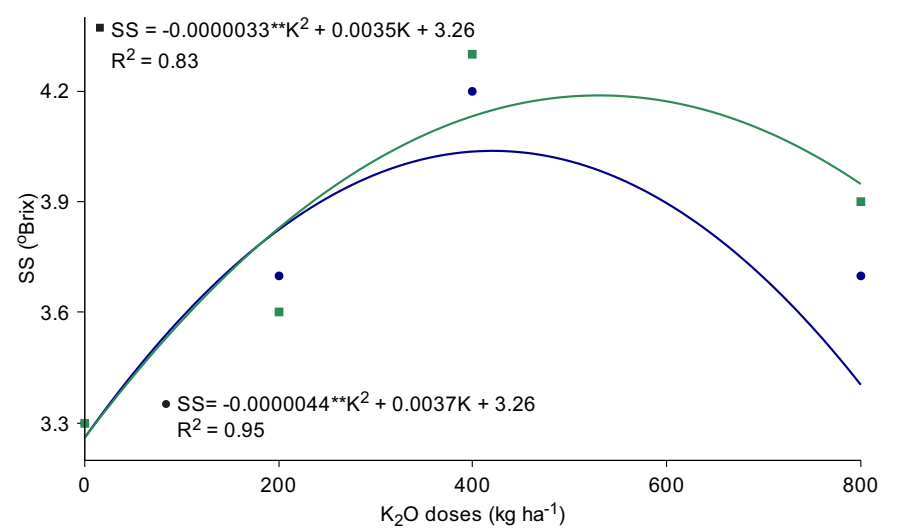

Figure 1. Soluble solids (SS) in tomato fruits as a function of potassium doses through conventional application and fertigation (

solids in the fruits, compared with plants fertilized through the conventional form at the doses of 400 and $800 \mathrm{~kg} \mathrm{ha}^{-1}$ of $\mathrm{K}_{2} \mathrm{O}$. For this variable, the quadratic model showed the best fit.

According to these models, the plants would produce maximum soluble solids of 4.04 and $4.19{ }^{\circ} \mathrm{Brix}$ in the fruits with the estimated doses of 420.45 and $530.30 \mathrm{~kg} \mathrm{ha}^{-1}$ of $\mathrm{K}_{2} \mathrm{O}$, through conventional application and fertigation, respectively.

The values of SS (4.15 and $4.27^{\circ} \mathrm{Brix}$ ) observed in the present study at the dose of $400 \mathrm{~kg} \mathrm{ha}^{-1}$ of $\mathrm{K}_{2} \mathrm{O}$ with the conventional method and fertigation are consistent with the indication of Giordano et al. (2000), who recommend a minimum value of $4.0^{\circ} \mathrm{Brix}$ for the tomato processing industry. The values of SS obtained with the other tested doses remained below the recommendation of the authors and, in this case, the fruits can be used for fresh consumption.

Koetz et al. (2010) point out that, the higher the content of ${ }^{\circ}$ Brix in the fruits, the lower the consumption of energy to obtain the concentrated pulp in the industry. The content of soluble solids in the fruits, besides being a genetic characteristic of the cultivar, can be influenced by temperature, irrigation and fertilization (Raupp et al., 2009).

According to the regression analysis (Figure 2), fertigated plants showed higher values of titratable acidity in the fruits, in comparison to those fertilized through the conventional method, for the dose of $800 \mathrm{~kg} \mathrm{ha}^{-1}$ of $\mathrm{K}_{2} \mathrm{O}$. The linear model showed the best fit for both methods.

Results contrary to those of the present study were reported by Blanco \& Folegatti (2008), who studied K fertilization in the tomato crop, and by Genúncio et al. (2010), who tested different $\mathrm{K}$ concentrations in the tomato crop in hydroponic and fertigated systems.

It is observed (Figure 3) that the quadratic model showed the best fit for both forms of $\mathrm{K}$ application. According to the obtained models, the plants would exhibit maximum SS/TA ratios of 11.12 and 11.84, at the estimated doses of 300 and $465 \mathrm{~kg} \mathrm{ha}^{-1}$ of $\mathrm{K}_{2} \mathrm{O}$, through conventional application and fertigation, respectively.

It should be remembered that tomato fruits can be considered as tasty when they have SS/TA ratio above 10 (Kader et al., 1978). Guimarães et al. (2008), working with the tomato crop, observed values higher than 10 for the SS/

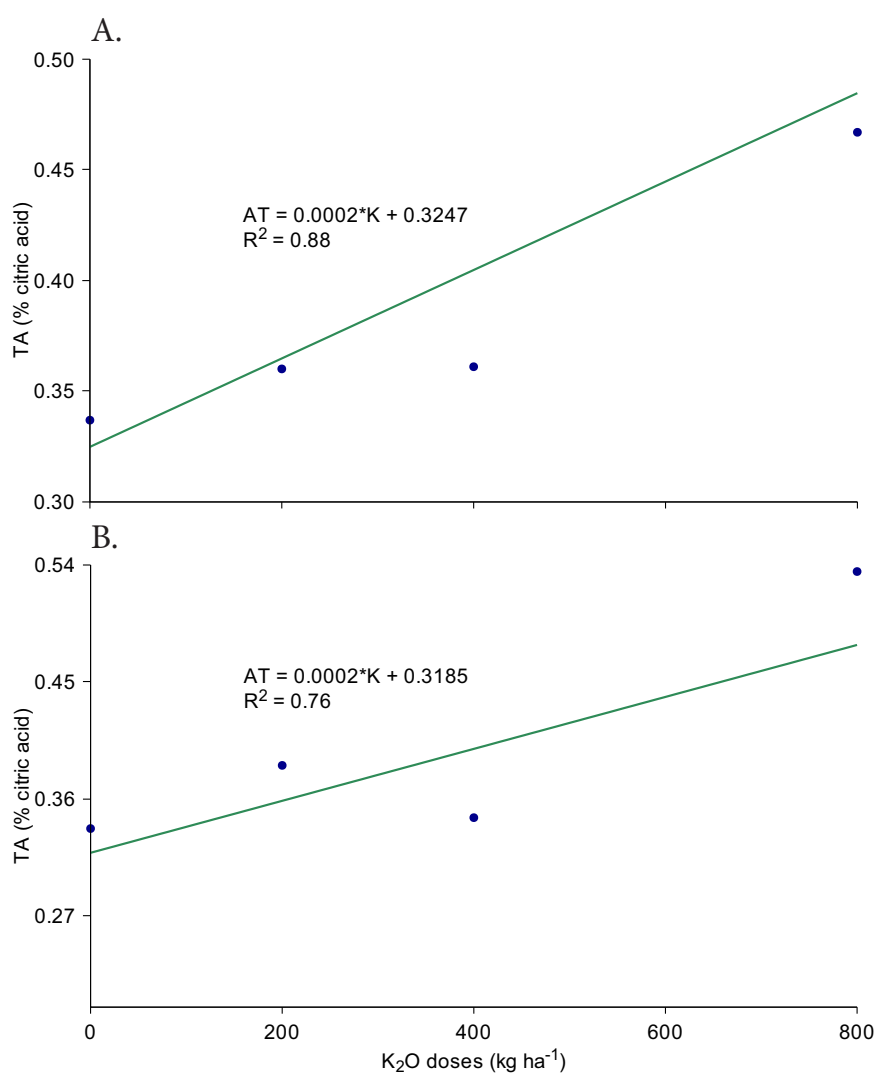

Figure 2. Titratable acidity (TA) in tomato fruits as a function of potassium doses through conventional application (A) and fertigation (B)
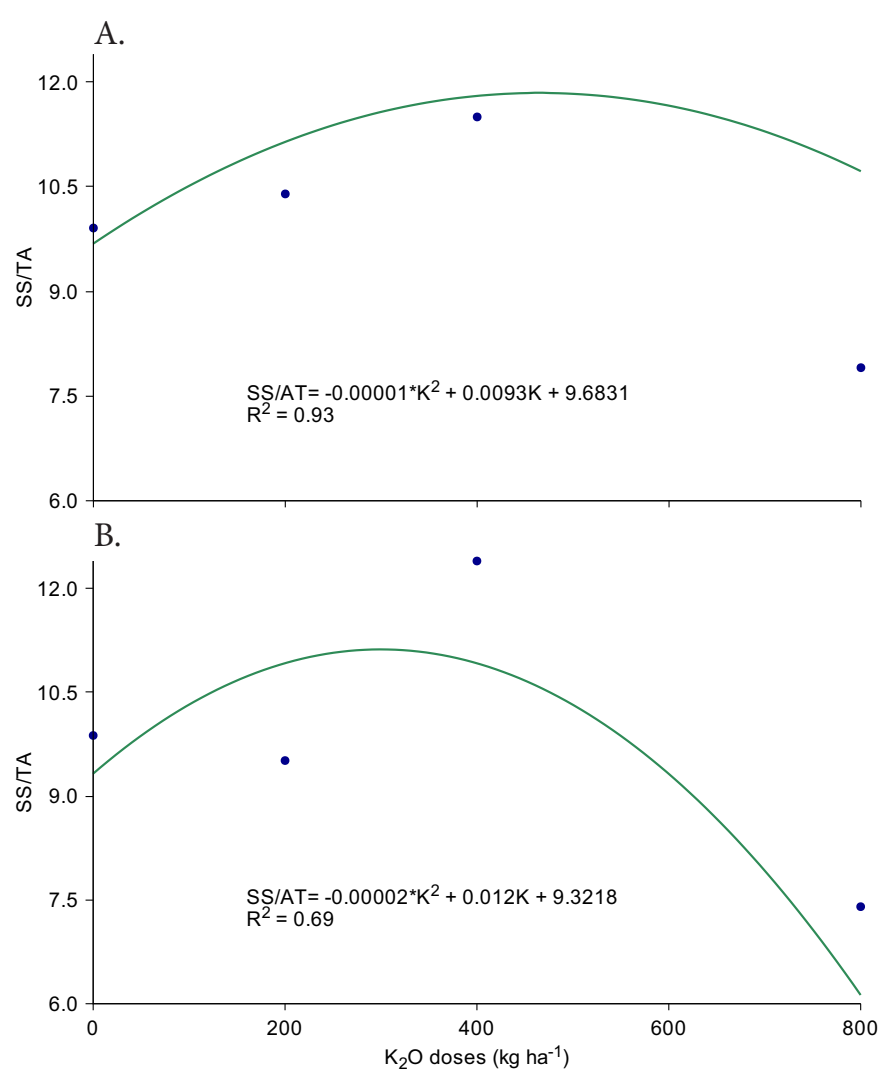

Figure 3. Ratio between soluble solids and titratable acidity (SS/TA) in tomato fruits as a function of potassium doses through conventional application (A) and fertigation (B)

TA ratio, superior to those obtained at the lowest and highest dose of $\mathrm{K}_{2} \mathrm{O}$. 


\section{Conclusions}

1. Potassium fertilization applied through fertigation (400 $\mathrm{kg} \mathrm{ha}^{-1}$ of $\mathrm{K}_{2} \mathrm{O}$ ) increases the content soluble solids and the ratio between soluble solids and titratable acidity of tomato fruits.

2. Thus, fertigation is a more promising method for $\mathrm{K}$ application, because it allows a greater fractionation of the doses to be applied.

\section{Literature Cited}

Allen, R. G.; Pereira, L. S.; Paes, D.; Smith, M. Crop evapotranspiration: Guidelines for computing crop water requirements. Roma: FAO, 1998. 328p. Irrigation and Drainage Paper, 56

AOAC - Association of Official Agricultural Chemists. Official methods of analysis of the Association of the Agricultural Chemists. 12.ed. Washington: AOAC, 1992. 52p.

Blanco, F. F.; Folegatti, M. V. Doses de N e K no tomateiro sob estresse salino: III. Produção e qualidade de frutos. Revista Brasileira de Engenharia Agrícola e Ambiental, v.12, p.122-127, 2008. http:// dx.doi.org/10.1590/S1415-43662008000200003

Dorais, M.; David, L. E.; Papadopoulos, A. P. Tomato (Solanum lycopersicum) Health components: From the seed to the consumer. Phytochemistry Reviews, v.7, p.231-250. 2008. http://dx.doi. org/10.1007/s11101-007-9085-x

EMBRAPA - Empresa Brasileira de Pesquisa Agropecuária. Sistema brasileiro de classificação de solos. 2.ed. Rio de Janeiro: Embrapa Solos, 2006. 306p.

FAO - Organização das Nações Unidas para a Agricultura e Alimentação. <http://faostat3.fao.org/faostat-gateway/go/to/download/Q/QC/S>. 7 Out. 2013.

Ferreira, S. M. R.; Quadros, D. A.; Karkle, E. N. L.; Lima, J. J.; Tullio, L. T.; Freitas, R. J.S. Qualidade pós-colheita do tomate de mesa convencional e orgânico. Ciência e Tecnologia de Alimentos, v.30, p.858-864. 2010. http://dx.doi.org/10.1590/S0101-20612010000400004

Ganez, K.; Alexander, M.; Corredig, M. In situ study of flocculation of whey protein-stabilized emulsions caused by addition of high methoxyl pectin. Food hydrocolloid, v.20, p.293-298, 2006. http:// dx.doi.org/10.1016/j.foodhyd.2005.02.022

Genúncio, G. C.; Silva, R. A. C.; Sá, N. M.; Zonta, E.; Araújo, A. P. Produção de cultivares de tomateiro em hidroponia e fertirrigação sob razões de nitrogênio e potássio. Horticultura Brasileira, v.28, p.446-452, 2010. http://dx.doi.org/10.1590/S0102-05362010000400012

Giordano, L. B.; Silva, J. B. C.; Barbosa, V. Escolha de cultivares e plantio. In: Silva, J. B. C.; Giordano, L. B. (org.). Tomate para processamento industrial. Brasília: Embrapa Comunicação para Transferência de Tecnologia/Embrapa Hortaliças, 2000. p.36-59.

Guimarães, M. de A.; Silva, D. J. H. da; Fontes, P. C. R.; Mattedi, A. P. Produtividade e sabor dos frutos de tomate do grupo salada em função de podas. Bioscience Journal, v.24, p.32-38, 2008.

IBGE - Instituto Brasileiro de Geografia e Estatística. Censo Agropecuário 2006. <http://www.ibge.gov.br>. 25 Set. 2013.

IAL - Instituto Adolfo Lutz. Normas analíticas do Instituto Adolfo Lutz: Métodos químicos e físicos para análise de alimentos. São Paulo: IAL, 2005. 533p.

IAC - Instituto Agronômico de Campinas. Recomendações de adubação e calagem para o estado de São Paulo. 2.ed. São Paulo: IAC, 1996. 285p. Boletim Técnico, 100
Kader, A. A.; Morris, L. L.; Stevens, M. A.; Albright-Holton, M. Composition and flavor quality of fresh market tomatoes as influenced by some post harvest handling procedures. Journal of American Society for Horticultural Science, v.113, p.742-745, 1978.

Kanai, S.; Moghaieb, R. E.; El-Shemy, H. A.; Panigrahi, R.; Mohapatra, P. K.; Ito, J.; Nguyen, N. T.; Saneoka, H.; Fujita, K. Potassium deficiency affects water status and photosynthetic rate of the vegetative sink in green house tomato prior to its effects on source activity. Plant Science, v.180, p.368-374, 2011. http://dx.doi. org/10.1016/j.plantsci.2010.10.011

Koetz, M.; Masca, M. G. C. C.; Carneiro, L. C.; Ragagnin, V. A.; Sena Júnior, D. G.; Gomes Filho, R. R. Caracterização agronômica e Brix em frutos de tomate industrial sob irrigação por gotejamento no sudoeste de Goiás. Revista Brasileira de Agricultura Irrigada, v.4, p.14-22, 2010. http://dx.doi.org/10.7127/rbai.v4n 100022

Paiva, E. P.; Lima, M. S.; Paixão, J. A. Pectina: Propriedades químicas e importância sobre a estrutura da parede celular de frutos durante o processo de maturação. Revista Iberoamericana de Polímero, v.10, p.196-221. 2009.

Pereira, M. G.; Loss, A.; Beutler, S. J.; Torres, J. L. R. Carbono, matéria orgânica leve e fósforo remanescente em diferentes sistemas de manejo do solo. Pesquisa Agropecuária Brasileira, v.45, p.508514, 2010. http://dx.doi.org/10.1590/S0100-204X2010000500010

Raupp, D. S.; Gardingo, J. R.; Schebeski, L. S. dos; Amadeu, C. A.; Borsato, A. V. Processamento de tomate seco de diferentes cultivares. Acta Amazônica, v.39, p.415-422, 2009. http://dx.doi. org/10.1590/S0044-59672009000200021

Sampaio, R. A.; Fontes, P. C. R. Qualidade de frutos de tomateiro fertirrigado com potássio em solo coberto com polietileno preto. Horticultura Brasileira, v.16, p.136-139, 1998. http://dx.doi. org/10.1590/S0102-05361998160000200009

Santos, F. F. B. dos; Ribeiro, A.; Siqueira, W. J.; Melo, A. M. T de. Desempenho agronômico de híbridos $\mathrm{F}_{1}$ de tomate de mesa. Horticultura Brasileira, v.29, p.304-310, 2011. http://dx.doi. org/10.1590/S0102-05362011000300008

Schwarz, D.; Oztekin, G. B.; Tuzel, Y.; Bruckner, B.; Krumbein, A. Rootstocks can enhance tomato growth and quality characteristics at low potassium supply. Scientia Horticulture, v.143, p.70-79, 2013. http://dx.doi.org/10.1016/j.scienta.2012.06.013

Sousa, G. G. de; Azevedo, B. M. de; Oliveira, J. R. R. de; Mesquita, T. de O.; Vianna, T. V. de A.; Ó, L. M. G do. Adubação potássica aplicada por fertirrigação e pelo método convencional na cultura do amendoim. Revista Brasileira de Engenharia Agrícola e Ambiental, v.17, p.1055-1060. 2013. http://dx.doi.org/10.1590/ S1415-43662013001000005

Vasconcelos, D. V.; Sousa, V. F. de; Viana, T. V. de A.; Azevedo, B. M. de; Sousa, G. G. de; Cavalcante Júnior, J. A. H. Interação entre níveis de irrigação e fertirrigação potássica na cultura do maracujazeiro. Revista Irriga, v.18, p.160-170. 2013. http://dx.doi.org/10.15809/ irriga.2013v18n1p160

Zhao-Hiu, L.; Li-Hua, J.; Xiao-Lin, L.; Hardter, H.; Wen-Jun, Z.; YuLan, Z.; Dong-Fend, Z. Effect of N and $\mathrm{K}$ fertilizers on yield and quality of greenhouse vegetable crops. Pedosphere, v.18, p.496502, 2008. http://dx.doi.org/10.1016/S1002-0160(08)60040-5 